\title{
PREDIKTOR ASMA PADA USIA 7 TAHUN SETELAH MENDERITA BRONKIOLITIS AKUT KARENA RESPIRATORY SYNCYTIAL VIRUS: SUATU STUDI PROSPEKTIF
}

\section{PREDICTORS OF ASTHMA AT AGE 7 AFTER RESPIRATORY SYNCYTIAL VIRUS BRONCHIOLITIS: A PROSPECTIVE STUDY}

\author{
HMS. Chandra Kusuma \\ Laboratorium IImu Kesehatan Anak Fakultas Kedokteran Universitas Brawijaya / RSU dr. Saiful Anwar Malang
}

\begin{abstract}
Infants are at increased risk of developing asthma after RSV (Respiratory Syncytial Virus) acute bronchiolitis. The hypothesis that cytokine production is related to the development of asthma after RSV bronchiolitis. The diagnosis of RSV bronchiolitis was verified using the Abbott test pack RSV, a rapid enzyme immuno assay for direct detection of viral antigen in nasopharyngeal secretion. Changes in FEV1 (Forced Expiratory Volume in 1 second) were determined using spirometri, IL-4 and IFN- $\gamma$ levels were determined using the enzyme-linked immunosorbant assay (ELISA) method. In this study, 62 children hospitalized for RSV bronchiolitis were followed prospectively, 55 (88.7\%) children completed the study and 41 children (74.5\%) had asthma at 7 years of age. RSV bronchiolitis children were more frequent among boys (boy /girl ratio: 2). Episodes of wheezing more than 8 had specifity and sensitivity of $100 \%$ respectivelly, might be the very useful predictor for asthma. The cut off level over $40.84 \mathrm{pg} / \mathrm{ml}$ for IL-4, below $14.12 \mathrm{pg} / \mathrm{ml}$ for IFN- $\gamma$, IL-4 / IFN- $\gamma$ ratio over 3 and episodes of wheezing over 8 may be used to predict asthma after RCV bronchiolitis. Infants with asthma had higher IL-4 levels $(p=0.004)$ lower levels of IFN- $\gamma(p=0.599)$, higer IL-4 / IFN- $\gamma$ ratio $(p=0.000)$ and higer episodes of wheezing $(p=0.000)$ when compared with those who had no asthma. In conclusions, the higher levels of IL-4, higher IL-4 IFN- $\gamma$ ratio, lower IFN- $\gamma$ levels at the time of RSV bronchiolitis and higher episodes of wheezing may be used to predict asthma after RSV bronchiolitis later in life.
\end{abstract}

Key words: respiratory syncytial virus (RSV), bronchiolitis, asthma, IL-4, IFN- $\gamma$, IL-4 / IFN- $\gamma$ ratio, wheezing episodes, FEV1.

\section{PENDAHULUAN}

Penderita bronkiolitis akut yang dirawat inap mempunyai risiko tinggi untuk mengalami mengi berulang dan penurunan faal paru sampai usia 7 - 11 tahun. Jika penyebab bronkiolitis adalah Respiratory Syncytial Virus (RSV) maka risiko untuk terjadinya serangan mengi berulang dan penurunan faal paru sampai usia $7-11$ tahun menjadi makin meningkat $(1,2,3)$. Asosiasi epidemiologi antara bronkiolitis RSV dengan serangan mengi berulang dan asma dikemudian hari selalu menjadi perdebatan para ahli. Beberapa prediktor yang dapat menentukan terjadinya asma dikemudian hari antara lain: ibu atau ayahnya menderita asma, mempunyai saudara asma, serangan wheezing nya terjadi sebelum usia 2 tahun dan mengalami serangan sedikitnya 10 kali, sering mengalami infeksi saluran nafas bawah, bayi lahir prematur, bayi laki-laki, kemiskinan, ras kulit berwarna, tidak pernah mendapat ASI dan ibu perokok.

Penelitian-penelitian untuk membuktikan adanya hubungan tersebut terutama difokuskan pada mekanisme imunologis terjadinya disregulasi pola sitokin. Ketidakseimbang-

Jurnal Kedokteran Brawijaya, Vol. XXII, No. 3, Desember 2006 Korespondensi: HMS Chandra K; Laboratorium IKA Fakultas Kedokteran Unibraw/RSU dr. Saiful Anwar Malang; Jl. Jaksa Agung Suprapto no. 2 Malang; 0341 - 343343 an atau terjadinya pergeseran dari sel T-helper (Th) tipe 1 dan tipe 2 (Th1 dan Th2) dan pada respon sitokin yang diproduksi merupakan ranah penelitian yang banyak dilakukan baik terhadap penderita maupun pada model binatang percobaan (4). Walaupun demikian beberapa peneliti tidak menemukan adanya hubungan antara bronkiolitis RSV dimasa bayi dengan terjadinya asma pada masa anak-anak $(5,6)$.

Tujuan penelitian ini adalah untuk mencari prediktor terjadinya asma pada usia 7 tahun setelah menderita bronkiolitis akut karena RSV dimasa bayi dan sekaligus untuk membuktikan adanya gangguan keseimbangan produksi sitokin pada saat menderita bronkiolitis akut RSV dimasa bayi.

\section{METODE}

Semua penderita yang masuk rumah sakit dan dirawat dibagian anak RSU dr. Saiful Anwar, Rumah Sakit Lavalette dan Rumah Sakit Islam di Malang dengan diagnosa bronkiolitis akut diikutkan dalam penelitian ini. Penelitian dilakukan sepanjang Januari sampai dengan Desember 2003 dengan kriteria inklusi sebagai berikut : usia dibawah atau sama dengan 2 tahun, baru pertama kali dirawat inap dan di diagnosa sebagai bronkiolitis akut, lahir aterm dengan berat badan lahir > 2500 gram, belum pernah di rawat dan di diagnosa asma, tidak ada kelainan di sistim pernafasannya, tidak mendapat kortikosteroid, tidak mendapat 
antivirus dan tidak menderita penyakit gangguan imun. Orang tua penderita telah diberitahu (informasi tentang maksud dan tujuan penelitian) dan apabila telah memahami maka diminta menandatangani persetujuan tertulis untuk ikut serta dalam penelitian (informed consent). Penelitian ini sudah disetujui oleh Komite Etik Penelitian Fakultas Kedokteran Universitas Brawijaya / RSU dr. Saiful Anwar Malang.

Pemeriksaan dan pengukuran kadar IL-4 dan IFN- $\gamma$ yang diambil dari darah tepi menggunakan metode enzyme linked immuno assay (ELISA, BMS 225/2 dan BMS 228) yang diambil pada saat dirawat inap karena bronkiolitis akutnya. Pemeriksaan keberadaan virus RSV dilakukan dengan menggunakan test pack RSV (Abbot list 2027 - 16) dengan metode rapid enzyme immuno assay untuk mendeteksi antigen virus secara langsung yang diambil dari sediaan sekresi lendir nasofaring. Pengukuran faal paru menggunakan Spirometer Auto Spiror discom 21 sesuai prosedur. Diagnosa asma dibuat atas dasar kriteria asma Unit Kerja Koordinasi (UKK) Respirologi Pengurus Pusat lkatan Dokter Anak Indonesia (PP IDAI) (7).

Penderita diminta datang apabila ada gejala batuk disertai sesak atau sedikitnya 6 bulan sekali untuk dilakukan pendataan terhadap adanya serangan mengi yang terjadi selama penelitian. Penderita diikuti sejak pulang dari rumah sakit sampai dengan usia 7 tahun. Analisis statistik menggunakan program SPSS Vs 10.0.

Analisa statistik kontribusi, cut of point, akurasi, sensitifitas dan spesifikasi variabel IL-4, IFN-4 $\gamma$, IL-4 / IFN- $\gamma$, wheezing menggunakan program SPSS Vs 10.0.

\section{HASIL PENELITIAN}

Dari hasil pengumpulan penderita bronkiolitis akut yang dirawat inap berhasil dikumpulkan 135 anak. Sejumlah
62 anak terbukti merupakan bronkiolitis akut RSV. Penderita yang mengikuti penelitian sampai selesai dari 62 penderita bronkiolitis akut adalah 55 orang $(88,71 \%)$. Dari data yang berhasil dikumpulkan ternyata bronkiolitis akut RSV lebih sering terjadi pada anak laki-laki (Rasio laki-laki / perempuan $=2,06)$. Dari 55 penderita bronkiolitis akut RSV yang berkembang menjadi asma adalah 41 orang $(74,54 \%)$.

Dari tabel 1 terlihat bahwa umur (dalam bulan) tidak perbedaan yang bermakna antara kedua kelompok tetapi terlihat bahwa jumlah serangan wheezing selama penelitian, nilai FEV1, diatas usia 6 tahun kadar IL-4 dan rasio IL-4/ IFN$\gamma$ pada awal masuk rumah sakit sulit terlihat lebih tinggi pada penderita asma pasca bronkiolitis RSV dan kadar IFN- $\gamma$ lebih rendah

Dari tabel 2 dapat diketahu bahwa variabel petanda kejadian asma yang terbaik adalah jumlah serangan wheezing yang terjadi selama penelitian, yaitu memiliki tingkat akurasi, sensifitas dan spesifitas yang semuanya $100 \%$. Artinya dengan nilai cut of point $=8$ (diatas nilai tersebut akan menjadi asma), hasil prediksi kejadian asma atau tidak asma memiliki tingkat akurasi yang sangat tinggi. Sedangkan rasio IL-4 / IFN- $\gamma$ walaupun akurasi dan sensifitasnya tidak $100 \%$ tetapi mempunyai spesifitas $100 \%$. Adapun IFN- $\gamma$ kurang layak digunakan sebagai petanda asma, mengingat tingkat signifikasinya rendah $(\mathrm{p}=$ 0.599); berbeda dengan IL-4 yang memiliki akurasi $94.12 \%$ dan spesifitas $100 \%$. Dengan demikian, maka kadar IL-4 diatas $40.84 \mathrm{pg} / \mathrm{ml}$, IFN- $\gamma$ dibawah $14.12 \mathrm{pg} / \mathrm{ml}$ rasio IL-4 I IFN- $\gamma$ dibawah 3 dan serangan wheezing lebih dari 8 kali dapat menjadi prediktor kejadian asma pasca bronkiolitis RSV.

Tabel 1. Hasil Analisis Diskriptif Penderita Bronkiolitis Akut RSV

\begin{tabular}{lcccc}
\hline \multirow{2}{*}{ Variabel } & \multicolumn{2}{c}{ Asma $\oplus$} & \multicolumn{2}{c}{ Asma $\Theta$} \\
\cline { 2 - 5 } & Mean & SD & Mean & SD \\
\hline Umur (Bulan) & 18.3 & 3.7 & 18.7 & 3.8 \\
Wheezing (kali) & 11 & 3 & 2 & 1 \\
FEV1 (\%) & 61.32 & 8.19 & 92.71 & 6.40 \\
IL-4 (pg/ml_) & 46.82 & 26.47 & 23.88 & 11.88 \\
IFN- $\gamma$ (pg/ml) & 12.92 & 6.58 & 16.77 & 6.31 \\
IL-4 / IFN- $\gamma$ (Rasio) & 3.96 & 2.06 & 1.47 & 0.51 \\
\hline
\end{tabular}

Tabel 2. Evaluasi Setiap Variabel Sebagai Petanda Kejadian Asma

\begin{tabular}{lcccccc}
\hline \multicolumn{1}{r}{ Variabel } & $p$ & Kontribusi (\%) & Cut of Point ${ }^{*}$ & Akurasi (\%) & Sensitivitas (\%) & Spesifikasi \\
\hline IL-4 & 0.004 & 00.97 & 40.84 & 94.12 & 60.78 & 100 \\
IFN- $\gamma$ & 0.599 & 0.42 & 14.12 & 58.82 & 35.29 & 70.59 \\
IL-4 / IFN- $\gamma$ & 0.000 & 32.15 & 3.05 & 79.40 & 72.55 & 100 \\
Wheezing & 0.000 & 71.00 & 8. & 100. & 100. & 100. \\
\hline
\end{tabular}

Keterangan :

$\left.{ }^{*}\right)$ = nilai diatas cut of point akan terjadi asma dan sebaliknya

$\left.{ }^{* *}\right)=$ nilai dibawah cut of point akan terjadi asma dan sebaliknya 


\section{DISKUSI}

Asma merupakan suatu penyakit radang kronis disaluran nafas. Terdapat hubungan antara infeksi virus, immunitas seluler dan perkembangan asma dikemudian hari (14). Pada penelitian-penelitian mutakhir dibuktikan bahwa mediator-mediator limfosit merupakan kunci utama imunitas seluler maupun humoral yang mempunyai peran utama dalam hal terjadinya sel linfosit T didalam darahnya dan melepaskan sitokin yang berasal dari sel $\mathrm{TH}_{2}$ yaitu IL-4 yang berlebihan atau menimbulkan produksi IFN- $\gamma$ yang sangat berkurang (8).

Dilakukan analisis apakah produksi sitokin yang abnormal mempunyai hubungan dengan terjadinya asma pasca bronkiolitis akut RSV dengan mengukur kadar IL-4 dan IFN- $\gamma$ dari darah tepi pada saat penderita dirawat inap di rumah sakit karena bronkiolitis akutnya dengan membandingkan kadar pada penderita yang menjadi asma dan kadar pada penderita yang tidak menjadi asma. Peneliti mendapatkan bahwa terjadi peningkatan kadar IL-4, Rasio IL-4 I IFN- $\gamma$ dan jumlah serangan wheezing yang sangat bermakna (masing-masing dengan $p=0.0004, p=0.000, p=0.000$ ). Penelitian ini sangat berbeda dengan hasil penelitian Renzi dkk yang justru mendapatkan bahwa terdapat korelasi positif yang bermakna antara bronkiolitis akut yang menjadi asma dengan penurunan kadar IFN- $\gamma(p=0.002)$, tapi tidak menunjukkan perbedaan yang bermakna kadar IL-4 diantara penderita bronkiolitis akut yang menjadi asma dengan penderita bronkiolitis akut yang tidak menjadi asma (9). Bahkan diperoleh hasil penelitian yang sangat berbeda yaitu kadar IFN- $\gamma$ pada penderita yang menjadi asma dan yang tidak menjadi asma tidak berbeda bermakna $(p=0.599)$ tetapi kenaikan kadar IL-4 pada penderita bronkiolitis akut RSV yang menjadi asma dibandingkan dengan yang tidak menjadi asma sangat berbeda bermakna dengan $p=0.004$. Dari analisis rasio IL-4 / IFN- $\gamma$, kadar IL-4 dan kadar IFN- $\gamma$ maka penentuan rasio antara IL-4 dan IFN- $\gamma$ tampaknya lebih memberikan perbedaan yang bermakna $(p=0.000)$ dibandingkan dengan masing-masing variabel IL-4 dan IFN- $\gamma$ sendiri. Penelitian yang dilakukan oleh Legg dkk membuktikan bahwa terjadi peningkatan rasio IL-4 / IFN- $\gamma$ dan kadar IL-4 yang bermakna pada penderita bronkiolitis akut RSV dan menyatakan bahwa ada implikasi kuat terjadinya res- pon imun berlebihan tipe 2 dan / atau defisiensi respon imun tipe 1 dalam patogenesis bronkiolitis RSV (10).

IL-4 dan IFN- $\gamma$ merupakan pasangan yang menggambarkan paradigma tipe 2 dan tipe 1 yang saling mengatur keseimbangannya dengan saling menekan diantara keduanya, yaitu IFN- $\gamma$ menghambat perkembangan respon imun tipe 2 dan merangsang respon imun tipe 1, sebaliknya IL-4 menginduksi produksi sitokin tipe 2 dan mensupresi respon imun tipe I $(13,14)$. Keseimbangan antara produksi sel Th1 (IFN- $\gamma$ ) dan sel Th2 (IL-4) sangat penting dalam terjadinya asma dan atopi (8-10). Seperti telah diketahui bersama IL-4 merupakan sitokin utama yang mengatur produksi IgE pada asma. Peningkatan produksi IL-4 memicu peningkatan kadar lgE melalui switching sel B ke sel plasma atau sel $\mathrm{TCD}_{4}{ }^{+}$berdiferensiasi menjadi sel Th2 (11-13). Dalam penelitian ini terjadi peningkatan kadar IL-4 dan rasio IL-4 / IFN- $\gamma$ yang bermakna pada penderita bronkiolitis akut RSV dimasa bayi dan berkembang menjadi asma pada usia 7 tahun. Terjadinya penurunan kadar IFN- $\gamma$ yang tidak bermakna pada penelitian ini menunjukkan bahwa ada kemungkinan mekanisme lain dalam timbulnya asma pasca bronkiolitis akut RSV. Walaupun demikian peningkatan kadar IL-4, rasio IL-4 / IFN- $\gamma$, penurunan IFN- $\gamma$ dan serangan mengi berulang dapat menjadi alat untuk memprediksi terjadinya asma pasca bronkiolitis akut RSV.

Implementasi secara klinis maka penderita pasca bronkiolitis akut RSV apabila sepanjang perjalanan hidupnya mengalami serangan wheezing sedikitnya 8 kali sudah dapat diprediksi akan berkembang menjadi asma dikemudian hari oleh karena $p=0.000$ dan akurasi, sensitifitas, dan spesifikasinya masing-masing $100 \%$. Dengan melakukan pemeriksaan IL-4, IFN- $\gamma$ dan rasio IL-4 / IFN- $\gamma$ kepada semua penderita bronkiolitis akut karena RSV pada saat dirawat di rumah sakit, maka dapat ditentukan prediksi penderita tersebut akan menjadi asma atau tidak.

\section{KESIMPULAN}

Penelitian ini membuktikan bahwa peningkatan kadar IL-4 dan rasio IL-4 / IFN- $\gamma$ pada saat menderita bronkiolitis akut RSV dapat menjadi alat untuk memprediksi terjadinya asma dikemudian hari. Meningkatnya serangan whezzing setelah bronkiolitis akut RSV dapat pula menjadi prediktor yang mudah dilakukan terhadap kejadian asma pasca bronkiolitis akut RSV.

\section{DAFTAR KEPUSTAKAAN}

1. Fjaerli HO, Farstad T, Rod G, et al. Acute bronchiolitis in infancy as risk factor for wheezing and reduced pulmonary function by seven years in Akershus County. Norway: BMC Pediatri ; 2005; .5: 31.

2. Stein RT, Sherril D, Morgan WJ, et al. Respiratory syncytial virus in early life and risk of wheeze and allergy by age 13 years. Lancet 1999; $354: 541$.

3. Martinez FD. Respiratory syncytial virus bronchiolitis and the pathogenesis of childhood asthma. Pediatr Infect Dis J 2003; 22: 576. 
4. Lemanske RF. Does respiratory syncytial viral - induced bronchiolitis result from helper $T$ cell type 1 / type 2 cytokine imbalance? Am J Respir Crit Care Med 2003; 168: 625 - 627.

5. Sigurs N, Bjarnason R, Sigurbergsson F, et al. Asthma and immunoglobulin E antibodies: a prospective cohort study with matched controls. Pediatrics 1995; 95: $500-506$.

6. Pullan C, Hey E. Wheezing, asthma, and pulmonary disfunction 10 years after infection with respiratory syncytial virus in infancy. Br Med J 1982; 5 : 1665 - 1669.

7. UKK Respirologi PP IDAI.. Konsensus Nasional Asma Anak. 2005

8. Ying S, Hambert M, Barkans J, et al. Expression of IL-4 and IL-5 mRNA and protein product by $C D_{4}{ }^{+}$and $C D_{8}{ }^{+} T$ cells, eosinophils, and mast cells in bronchial biopsies obtained from atopic and non atopic (intrinsic) asthmatics. Immunol 1997; 158: 3539 - 3544.

9. Renzi PM, Turgeon JP, Marcotte JE, et al. Reduced interferon- $\gamma$ production infants with bronchiolitis and asthma. Am J Respir Crit Care Med 1999; 159: 1417 - 1422.

10. Legg JP, Hussain IR, Warner JA, et al. Type 1 and type 2 cytokine imbalance in acute respiratory syncytial virus bronchiolitis. Am J Respir Crit Care Med 2003; 168: 633 - 639.

11. Renzi PM, Turgeon JP, Yang JP, et al. Cellullar immunity is activated and a Th2 response is associated with early wheezing in infants after bronchiolitis. J Pediatr 1997; $130: 584-594$.

12. Lebman DA, Coffman RL. Interleukin-4 causes isotype switching to IgE in T cell-stimulated clonal B cell cultures. J Exp Med 1988; 168: 853 - 862.

13. Pene J, Rousset $F$, Briere $F$, et al. IgE production by normal human $B$ cells induced by alloreactive $T$ cells clones is mediated by IL-4 and suppressed by IFN-gamma. J Immunol 1988; 141: 1218 - 1224.

14. Scott P. IFN-gamma modulates the early development of Th1 and Th2 responses in a murine model of cutaneous leishmaniasis. J Immunol 1991; 147: 3149 - 3155.

15. Maggi E, Paronchi P, Manetti R, et al. Reciprocal regulatory effects of IFN-gamma and IL-4 on the in vitro development of human Th1 and Th2 clones. J Immunol 1992; 148: 2142 - 2147.

16. Stein RT, Sherril D, Morgan WJ, et al. Respiratory syncytial virus in early life and risk of wheeze and allergy by age 13 years. Lancet 1999; 354: $541-545$.

17. Sigurs N, Bjarnason R, Sigurbergsson F, et al. Respiratory syncytial virus bronchiolitis in infancy is an important risk factor for asthma and allergy at age 7. Am J Respir Crit Care Made 2000; 161: 1501 - 1507. 